\title{
Key mine closure lessons still to be learned
}

\author{
CD McCullough Golder Associates Pty Ltd and Edith Cowan University, Australia
}

\begin{abstract}
The focus of mining project feasibility studies and operations is still on short-term profitability with little view to a post-closure landscape and liability. The faults of both the original and the operation's mine planners are therefore vested upon the closure teams who must deal with these planning decisions. Following completion of operations, most mining companies that have not adequately prepared for mine closure will face an inability to relinquish their project leases as a result of closure planning process shortfalls. Following from our own closure project experiences and of recent international mine closure conferences, we propose seven key lessons still to be learned if successful mine closure is to be achieved.
\end{abstract}

Firstly, a paucity of baseline environmental monitoring data often incapacitates good closure planning from the outset with a failure to understand key closure risks and risk drivers for the site. Well-characterised environmental information prior to mining disturbance and monitored progressive rehabilitation is a great strategy to address this fault.

An insufficient understanding of the physical and chemical characteristics and volumes of waste materials is a second critical fault of closure processes.

A third significant issue is contaminated mine waters such as acid and metalliferous drainage (AMD). $A M D$ is arguably one of the single biggest liabilities and management issue post-closure.

Failure to engage stakeholders in a documented process is a fourth prime failing often seen with the fifth of mine closure procrastination. Like all of these causes, this problem often arises from thinking mine closure is an activity at end of life-of-mine rather than as a process that begins with the initial mine plan and then regularly continues throughout mine life. Diligent attention to regular planning assessment and stakeholder consultation from an early operational phase may fend off later criticisms, lead to closure outcomes better directed by years of underpinning work and also reduce end of mine costs.

A sixth significant closure planning error is the failure to account for the long temporal scales that closure planning must accommodate, particularly so when costing closure. This failure is often due to closure views being short-term, to meet immediate regulatory and operational planning needs rather than focussed on the future.

A seventh lesson from historic closure planning is the simple failure to have clear closure objectives and approaches to identified outcomes. This may result in a focus on technical studies that fail to provide better closure understanding, whilst expending hard-won closure-aimed budgets. Driving closure planning by well-defined goals through corporate tools such as closure standards designed to meet both internal requirements and relevant closure guidelines is an ideal solution to avoiding wasted closure resources such as time and finances.

Whilst learning and addressing these key closure lessons is no guarantee of successful relinquishment, recognition of these issues and judicious planning to overcome them is more likely to present well-considered closure plans with greater chance of closure relinquishment in a sustainable socio-environmentally manner that maintains a company's and the broader mining industry's licence to operate into the future. 


\section{$1 \quad$ The consequences of poor mine closure planning}

Mine closure planning is a business strategy that seeks to reduce both risk and also increase end use value (Botha 2012). Increased beneficial end use of the land that was once mined can not only serve to benefit the broader environment, it can also assist with offsetting, formally or otherwise, remaining closure legacy risk (Figure 1).

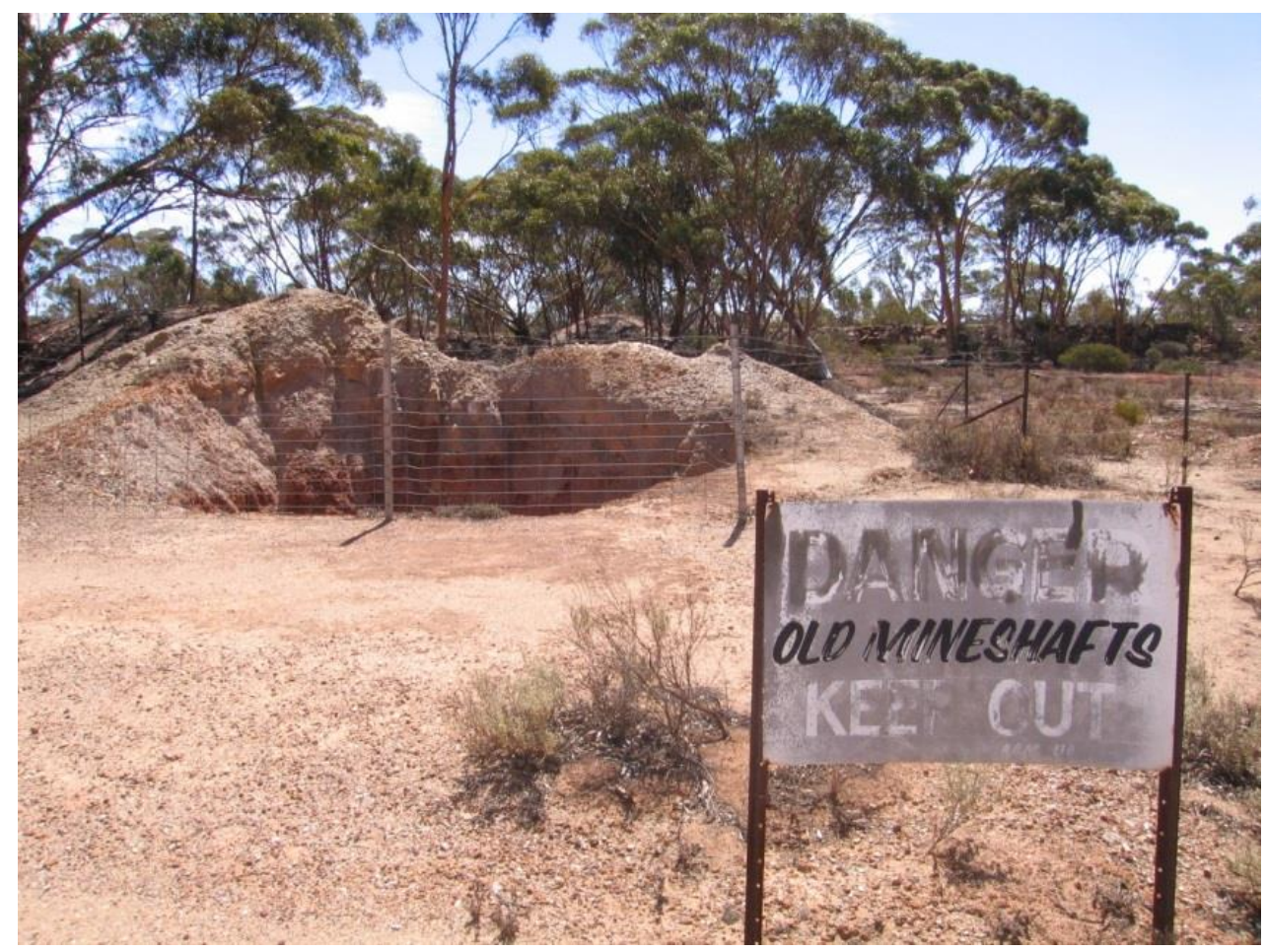

Figure 1 One of the many abandoned historic mine sites in the Western Australian Goldfields that stakeholders are aware of when considering new mining proposals

Poor mine closure planning can have a number of negative repercussions; both for the operating company, but also for the surrounding social and natural environment. Negative effects arising from poor closure are not always known at the time, but the risk of impacts could still often have been reduced through good planning processes (Jones \& Salmon 2012).

Direct effects on the environment can best be thought of in terms of two types of risk. The first risk is of damage to people and wildlife in the region, either immediate (through falls and land slips) or long term (through erosion and contamination) (Bridge 2004). The second risk is through changes to the stakeholder environment. Poor planning will increase chances of rejection by regulators and other stakeholders. Knock-on effects may be to increase difficulty in gaining other mining approvals for new sites/project extensions, delaying or even withholding proposed project approvals. Plan rejection will also cause further loss of social licence, delay relinquishment and increase closure cost. It may also lead to loss of stakeholder confidence and extend the required monitoring regime and detail (Nelson \& Scoble 2005).

\section{Insufficient data and over-reliance on estimates}

A paucity of baseline and monitoring data often incapacitates good closure planning by failing to understand the key closure risks and risk drivers at a site (Figure 2). Monitoring campaigns are often reduced during operations to those that meet operational requirements such as operating approvals, rather than including monitoring datasets that would provide data useful to closure. This lack of evidence may mean that positive operational activities and outcomes directly related to closure such as successful rehabilitation cannot then be demonstrated to the regulator or future owner of the land when final relinquishment is sought. 


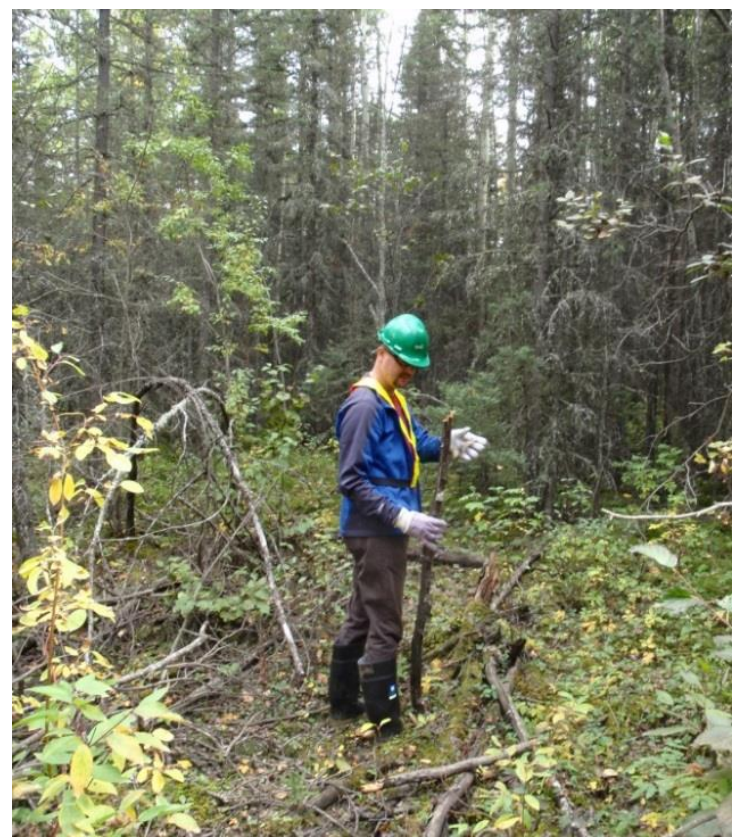

Figure 2 Without good baseline survey and monitoring data, this Canadian mine site would have to use baseline data alone for vegetation communities as reference analogue site communities are different from those found on the orebody

Studies and trials are an important tool for first understanding what constitutes closure risk and then whether management of closure risk will be successful. For example, monitoring water quality from waste rock dumps containing potential acid forming (PAF) cells can inform if the encapsulation, conceptually an attractive management strategy, is actually working for the site's specific characteristics of climate, geology and engineering technique. Monitoring progressive rehabilitation is great strategy to demonstrate, unequivocally, that closure outcomes such as rehabilitation success are being met (Zschiedrich 2004).

Monitoring is an essential tool for calibrating and validating predictive models. It has been well said elsewhere that 'all models are wrong but some are useful'. Models can be used predictively but are often fraught with risk of inaccurate predictive capability. This is especially so when considering the long-time scales (hundreds of years) they are often called upon to predict with datasets such as climate from mere decades. Of most concern, this inaccuracy and lack of reliability are typically wholly unquantified or worse still not even considered when interpreting model predictions. For example, long-term mine water quality modelling that requires long-term weathering data as a key input parameter (Castendyk et al. 2014). As much comfort to both regulators and industry that such crystal ball applications of models may give, modelling should also be considered as a tool key driver. However, whenever predictive models have been applied to direct closure strategy and design development these predictions should be assessed against monitoring data and re-calibrated as necessary (Vandenberg et al. 2011). Indeed, predictive models should be expected to be at their least reliable predictive capacity at the beginning of closure planning (when plans must therefore be robust), and most powerful at the detailed stages of closure planning (when planning flexibility is minimal and closure liability risk greatest).

Monitoring reference sites can also advise on trends in the natural environment; important when irrevocable changes have occurred to surrounding ecosystems such as are expected in many cases with climate change. Similarly, introduced pest plants and animals may become regionally established after mining begins, further changing what would reasonably constitute reference status for rehabilitation. Failure to monitor environmental changes in reference environments may lead to inappropriate objectives and criteria being followed; directions that are now irrelevant and in fact misleading given the changed environmental context the mine will be closed under. These data should be regularly captured from reference and other analogue monitoring sites and reported as part of the regular mine closure plan update process. 
In order for mining projects with predicted environmental impacts to proceed, environmental offsets may, be proposed (Dickinson \& Berner 2010). Environmental offsets are a final tool in the closure planners toolbox when an impact cannot be managed in one area; by providing greater environmental benefit (preferably in-kind) through enhancement activities elsewhere e.g. Newmont Golden Ridge Limited (2009). However, it is important that the value of these as biodiversity replacements are not over-stated as biodiversity and ecosystem function can be difficult to rehabilitate in impacted ecosystems (Maron 2012); and extremely difficult in poorly understood and novel ecosystems which rehabilitated mine lands constitute (Doley \& Audet 2013).

\section{Insufficient understanding of the physical and chemical characteristics and volumes of the waste material}

This problem may also be known as, 'I think they put reactive waste around here, somewhere...'.

An insufficient understanding of the physical and chemical characteristics and volumes of waste material is another critical fault of closure processes. The sins of both the original and the operations mine planners will be vested on the sons and daughters of closure teams bearing the consequences of these decisions with issues of unknown material type and placement often undefined even at the final closure stages.

In the ideal mining world, all waste landforms would consist of well-understood and neatly separated piles of non-dispersive, finer materials suitable as soil, and coarser materials suitable as armouring. These materials would be well-characterised for the prevailing erosive forces expected for the site; be it water erosion or wind erosion. The reality, as closure planning finds the material the operational phase has left it to work with, is often quite different. Due to the typical operational focus in mining, the situation presenting to closure planners is far more complex and problematic. Weathered cover and armouring materials may be buried within the waste rock dump (WRD) and intermixed with a heterogeneous conglomeration of dispersive and PAF materials. Erosion and water ingress may then lead to development and transport of contaminated waters (Figure 3) (Loch \& Vacher 2006).

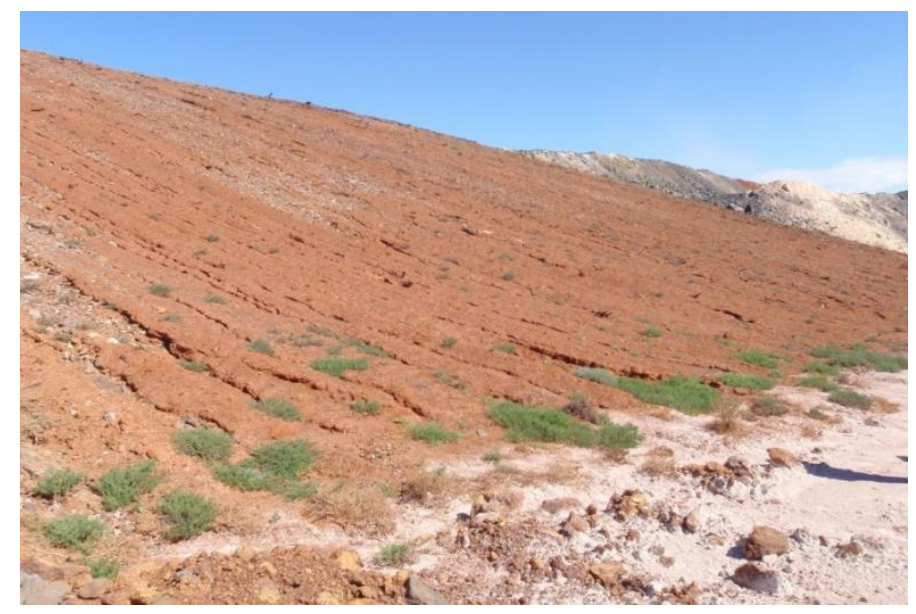

Figure 3 Erosion is the cause that will lead to symptoms such as AMD and failure to provide previous land use benefit for many poorly closed mine sites

Often the actual composition of waste landforms may be unknown due to changes from the original mining operation plan. Even if the original mining plan has been accurately followed, waste rock usually elicits little excitement and attention from site geologists as there is no value in further investigation; it is merely a nuisance to remove to get at the valuable resource. As a result, there is often a failure to document waste rock physico-chemical composition that is often not of import during operations. For example, key closure waste characteristics of dispersivity and chemically-polluting capacity such as PAF that will drive mine closure plans for waste dumps containing these materials, are essential to closure planners determining sustainable closure designs and strategies. For instance, materials may be best placed in-pit (even at 
greater operational costs for haulage) if out-of-pit landforms are not likely to be successful for closure (Puhalovich \& Coghill 2011).

Internationally, there is growing pressure from regulators to see progressive rehabilitation principles more explicitly considered in closure plans and better practiced on active mining sites. Performance bonds are increasingly including levies based upon areas of disturbance that may help drive this behaviour (Jones \& McCullough 2011; Jones 2012b). Alternatively, bonds defined only by an area of disturbance may equally led to some areas not becoming rehabilitated, or even rehabilitated area never being relinquished simply because it remains cheaper for mining companies to maintain these from the interest of a smaller sum as principal.

\section{$4 \quad$ Contaminated mine waters}

Mining and water are intrinsically linked. Mine waters also often present an insidious side of mine closure that may tarnish a social licence to mine for millennia after the resource has been exploited (Olias \& Nieto 2015) (Figure 4). Mining can contaminate waters through contact between highly geochemically enriched geologies and contact with natural water resources. Following poor waste management, waste landforms may develop contaminated mine waters such as acid and metalliferous drainage (AMD) at closure. AMD is arguably one of the single biggest liabilities from unsuccessful mine closure planning and can often be the biggest management issue post-closure such as treatment-in-perpetuity (Gammons \& Duaine 2006).

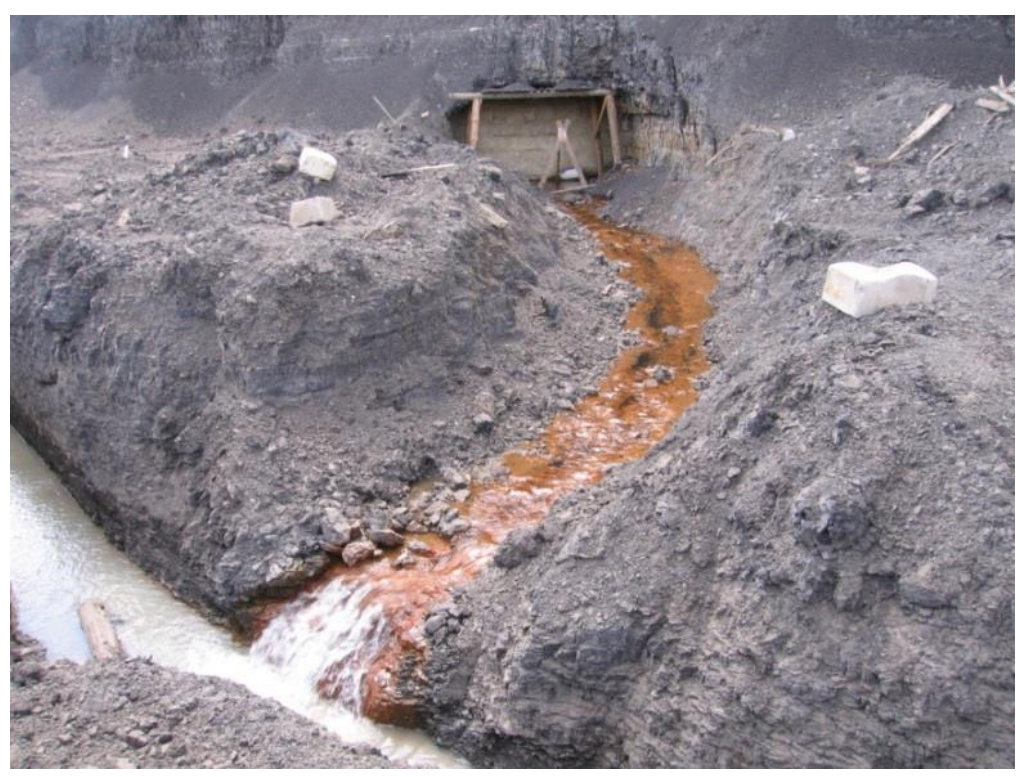

Figure 4 AMD seepage from an 11th Century silver mine, Czech Republic

Controlling mine waters (quality and quantity) is often the biggest mine closure risk left following abandonment (Younger 2002; McCullough \& Lund 2011). Combined with this, of all ecosystems potentially impacted by mining activities, aquatic habitats are especially threatened globally (Davidson 2014). Consequently, there is an increasingly large movement, predominantly driven by stakeholder views and implicitly by regulation, away from long-term water treatment at mine sites as water treatment is increasingly recognised as unsustainable.

Where mines impact upon rivers downstream, it is often for large distances before attenuation (or more often just simply dilution) remediates waters. Solute concentrations only slightly elevated may require little dilution to meet water quality guidelines relevant to closure objectives (McCullough \& Pearce 2014).

Conversely, when high contaminant concentrations are encountered, impact distance along a stream or river reach can often be from the source of contamination through to final receptor where the water ends such as a lake or sea. Ongoing treatment and remediation of mine closure in these circumstances is likely to be required. 
Poorly closed mining examples (Figure 3 ) through to modern examples provide a good basis for estimating long term closure treatment and cost requirements. These case studies indicate that (a) long-term water treatment may be required. Is perpetual water treatment more appropriate?. And (b), given point (a), what proportion of royalties and financial benefit from the mine that were originally garnered at regional, or even national scales, will then be consequently lost back to these ongoing treatment costs? Any annual treatment cost multiplied by perpetuity will be a very large number (Siwik \& Clemens 2015). The Berkeley site in Butte, Montana, now a US Superfund site, is a good example of this ongoing cost (Gammons \& Duaine 2006). Disposal of water treatment waste is also a significant issue and a large part of treatment costs, which will tend to move mines away from treatment.

When even clean excess water has become entrained on a mine site, the issue has often then become overflowing of tailings, pit voids or contaminated water storage ponds into these clean waters. Where water bodies overflow these may then contact waste geochemically elevated in elements then producing acidic or even neutral drainages (McCullough 2015).

As a key example of prophylaxis (avoidance) versus remedy (treatment), mine water quality remediation is more difficult to achieve than avoidance. Poor mine water quality inevitably occurs from weathering by water and oxygen (also chemical additives in the processing plants are sources of polluting agents that are carried to storage dams, tailings ponds etc.), contact with and transportation by water which has elevated concentrations presenting at environmental receptors.

Although perennial discharge of mine waters at closure to seasonal or ephemeral systems may be problematic, water quantity is not necessary a problem as long as the contained water quality is suitable for discharge, Vink (2012). In water scarce regions of the world, where many mines operate, there may be a business case for onward selling of treated water.

Conversely, if unable to be maintained dry and away from water (e.g. in high rainfall areas), then an alternative strategy may be to store waste in saturated conditions. Ideal storage is often in a backfilled pit rather than at constructed waste facilities that provide for greater areas of disturbance. Where pit voids extend below local groundwater levels then waste can be stored in saturated conditions (Schultze et al. 2011). However, prior to such storage being considered, consideration of groundwater flow paths such as by hydrogeological modelling should always be undertaken either specifically required by regulators such as contaminates lands legislation or as leading practice (McCullough et al. 2013b).

As waste storage facilities increasingly grow in magnitude and as the public becomes increasingly sensitised to failure of these large containment structures, Schaefer (2009), wet storage above the surface is increasingly fraught. New technologies such as thickened or even dry tailings may remedy these situations, but are not solutions to existing operations or historical mines.

It is usually more effective to treat inflows to pit lakes or other storage facilities such as tailings ponds than the outflow. New technologies may be forthcoming, for example, to treat AMD (McCullough \& Lund 2011). However, these treatments are often limited in application to specific situations, may be expensive and their performance unpredictable and currently remain unproven with many stakeholders and mining companies remaining unconvinced (Kumar et al. 2013a).

Equally, rather than reducing solute concentrations to meet water quality guidelines, increasing guideline criteria values may also be a reasonable approach. For example, due to the unique geochemistry that led to an interest in mining the project's region to begin with, many sites have elevated solutes in their host or even country rock (Eary \& Castendyk 2012). Previous historical or artisanal mining may also have led to geological disturbances and weathering increasing background concentrations above guideline levels (Banks et al. 1997). Given the purpose of most water quality guidelines is first to maintain water values by maintaining water quality at pre-disturbance levels, it may be a not unreasonable approach to develop site-specific water quality guidelines that are more site relevant than national or even international guidelines (Hickey \& Pyle 2001). 
Some mines are proactively minimising their disturbed land areas that have not yet been rehabilitated as a further way of reducing the risk of contaminated waters. An ideal goal is to have the majority of the mine already progressively rehabilitated and geochemically rendered inactive by the time the mine ends its operational phase and enters into the closure phase proper (Skousen \& Zipper 2014).

\section{$5 \quad$ Failure to engage stakeholders}

Failure to engage stakeholders in a documented process is a prime failing still identified in recent industry events that continue to plague most companies in the planning process. Buy-in and acceptance of the post-closure vision are key to successful closure outcomes. This arises from thinking mine closure is an activity at end of life-of-mine rather than as a process that begins with the initial mine plan and continues throughout mine life (ICMM 2008).

With increasing calls for transparency and from companies actively wishing to hear from (and influence) the stakeholders, leading industry practitioners are trying to move from a decide, announce, defend (DAD) model to dialog, decide, deliver (DDD), (Figure 5). Public consultation is often still inadequate; with too little occurring too late. Instead, closure stakeholder engagement needs to be: early, regular and honest (Charette \& Wylynko 2011).

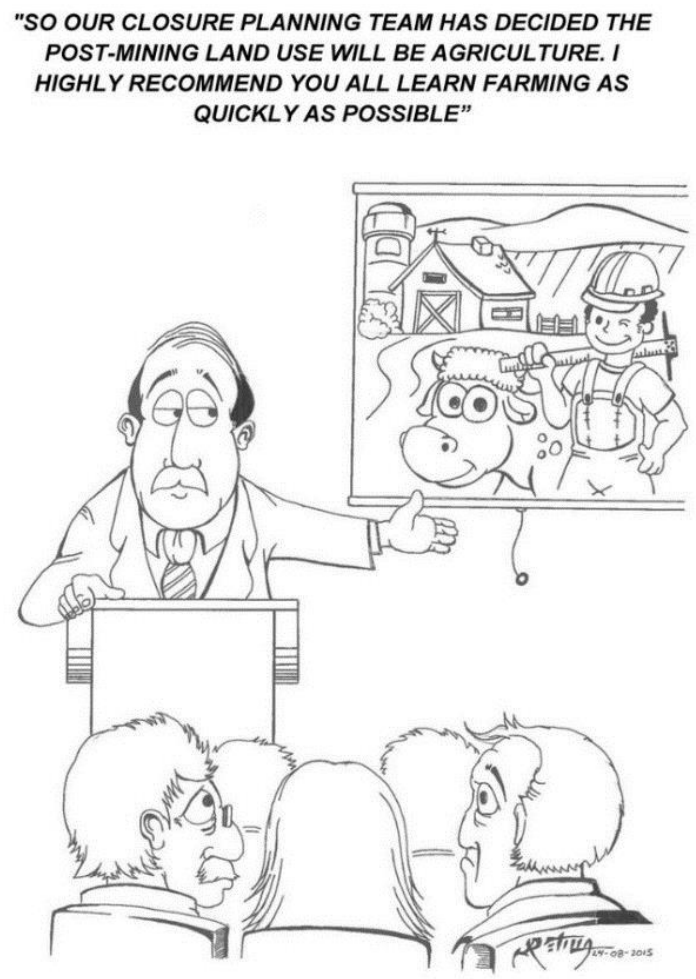

Figure 5 Stakeholder engagement means listening and not just informing

In particular, Traditional Owners are not stakeholders; they are Rights holders. They should be the first point of stakeholder engagement. The emphasis for Traditional Owners will often be on employment over other considerations. Employment must be considered in terms of closure and not just operational phases. And end of poverty and associated social ills and not just a hiatus. Traditional Owners may also have environmental standards in addition to those of the regulators, e.g. value for hunting and fishing. As such, Traditional Owners often represent a very tangible nexus between social and environmental assessments of end-land use and post-mining considerations.

Alternatively, fly-in, fly-out with a non-local workforce may reduce closure social liability as opposite to developing operational opportunities than then become defunct with the resulting social backlash of mine closure. 
Non-government organisations (NGOs) are often not engaged with but can become key interest parties once closure activities begin to be initiated. Active community groups such as NGOs can often be key vehicles for community interests, typically environmental and economic dimension, and allow some sharing of reputational risk. This collaboration can also provide a buffer against potentially more extreme views from parties such as some Traditional Owner and environmental groups.

Community individuals are often keen to get find out more about mine closure and rehabilitation plans, schedules, costs and monitoring data. However, communities are often not well-placed to understand the closure planning process. As a result of a lack of technical training and experience in the area, communities, in particular, will often interpret the data differently than regulators and industry. The resulting knowledge gap may result in typically negative speculation as the community and media as well abhor a vacuum and will fill it, even with misinformation, in light of no other sources. There is a need to provide educational opportunities to communities in the mining process so they understand the data and information supplied to them. Direct provision of or even support to attend third part presentations such as closure conferences may help these key stakeholders understand the closure path the mine is following.

An especially important beginning point is making clear to all affected communities that the mine will close someday and preparations must be made for this. Conversely, Traditional Owners may consider the mining operational phase merely a blink in time. However, dramatic changes to the landscape, even with good mine closure practices, may render the land's previous end-uses unavailable for many generations threatening inter-generational transfer of cultural knowledge and practices.

As a beginning, it can be very constructive if companies regularly request feedback from local communities as to whether they are satisfied with their level of involvement, and do so frequently. This is more than company communication of their closure plans and closure status. It is with two way dialog and true collaboration (Swanson 2011). Such collaboration expressed as joint decision-making or even joint-ownership should be a future goal for many mines operating on traditional lands.

Societies, including Indigenous cultures, are also very dynamic. Communities and community expectations are very likely to change over time. Sometimes this is due to external pressures, but most frequently simply due to having a mine in their midst as a significant socio-economic variable that was not there in the past. Frequent meetings with stakeholders including regulators may be necessary to track the closure planning process against changing stakeholder landscape of expectations and regulations (Siwik \& Clemens 2015), (Figure 6).

Hence the need for ongoing consultation for the life-of-mine and during closure, the solution is simple; engage early, engage often, and engage honestly and transparently. Failure to engage stakeholders in a documented process is often seen with the fifth problem of mine closure procrastination.

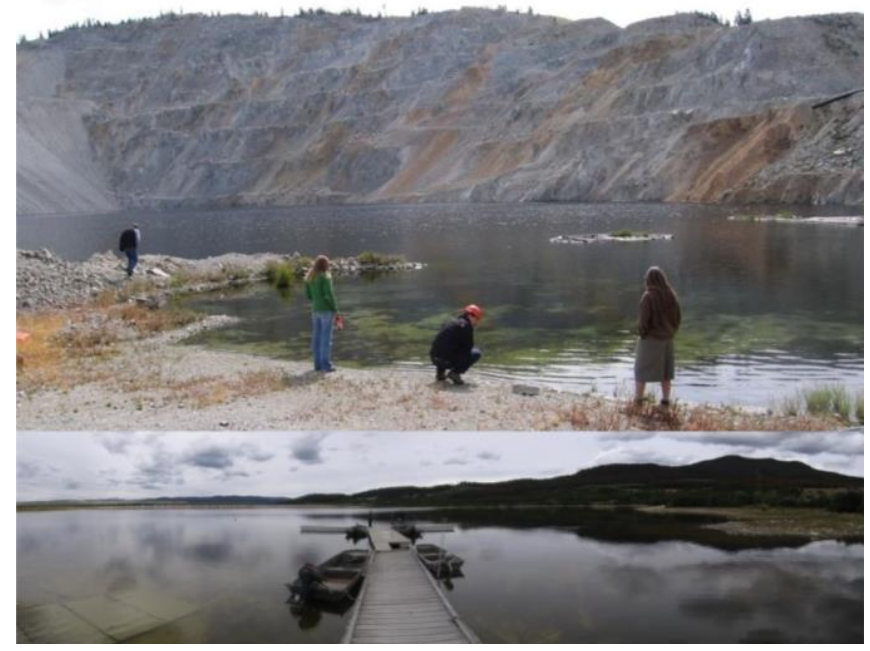

Figure 6 Stakeholder expectations may change over time. This British Columbian example shows that what is one generation's mine might be another's fishing and swimming lake 


\section{Procrastination}

Leaving closure planning to when the mine is about to close is a common error with mine closure planning. It fundamentally fails to recognise that closure planning is a process and not an event. It is not just writing a report for regulatory requirements, it is iteratively improving upon early concepts and strategies with increasingly better understanding of closure risks and risk mitigation performance.

Diligent attention to regular planning reassessment from an early operational phase may fend off later criticisms, lead to closure outcomes better directed by years of underpinning work and also reduce end of mine costs.

Planning continues through the life-of-mine, therefore it is not only the original mine planners but those planners that work through the operational period of the mine who should ensure a regular assessment of waste, water quality, landform stability, rehabilitation success etc. over the life-of-mine and ensure gaps in knowledge are filled during the operational phase of mining (Clark 1999).

Closure planning from the approval stage to final certification and relinquishment, with updated versions every $3-5$ years through the mine life, is now routine for the international industry. Although at a corporate level there is indication of good alignment between corporate and operational goals and consequently between the closure plan and actual operation, experience suggests this ideal is overstated with priorities for production. Most mining operations staff have commitments and key performance indicators (KPIs) at an hourly or daily level while closure planning is multi-year (Jones 2008).

Lack of planning is consequently often unintentional but habitual, delaying and disrupting the closure process. Failure to proactively plan for closure can be likened to being in a car with poorly designed brakes that is speeding toward a wall; the best a closure planner can often do with what the operation phases have afforded them at this stage is to recommend a brace position! All too often closure planners (either company staff or consultant) are tasked with producing a closure plan when a key failure to recognise closure as a process means that the real closure planning has already occurred long beforehand (Lord et al. 2015).

Increasingly regulators are not providing prescriptive regulation; more are expressing closure expectations in terms of guidance (DMP \& EPA 2011; CEMA 2012) and then reviewing forthcoming closure plans and assessing their reasonableness. This is not necessarily a bad approach, as overly prescriptive closure direction fails to recognise project-specific risks and closure requirements. However, many regulators struggle to effectively regulate mine closure, often simply from a staffing level, when the industry directly competes (very successfully) for well-qualified people with good experience. In these cases, industry is really a victim of its own success and needs to acknowledge the onus on itself to take the lead in good closure development and practice (Siwik \& Clemens 2015).

\section{$7 \quad$ Failure to plan for closure time scales}

A sixth significant closure planning mistake is failing to account for the long temporal scales that closure planning must accommodate, particularly so when costing closure. Given the nature of closure planning creating new landforms, it implicitly deals with large social and even environmental time scales. These scales will have gross relevance to human society, they far overlap historic scales, as can be seen from the closure legacies of historic mining in Europe (Nieto et al. 2013). For example, both regulatory criteria and social expectation are likely to change over time (moving goalposts). Closure plans having trouble meeting today's expectations and regulatory requirements are highly unlikely to meet social expectation in 10 or 20 years' time.

Long-time scales also mean that the rare but catastrophic events that typically sit at the bottom corner of closure risk matrices have a chance to be encountered. These events, often constituting seismic and flood events in particular, can turn closure planning rehabilitation works and expectations that were reasonable under normal conditions into environmental catastrophes (McCullough et al. 2013a). 
Unanticipated environmental extreme events often occur more frequently than anticipated, either predicted through historical datasets or by probabilistic modelling (which of course implicitly relies upon historical datasets). The key reason for this is simply that the real distribution of stochastic events vital to mine closure planning (rainfall, seismic events etc.) are often poorly documented and in turn understood. Mining in regions well away from human habitation, especially that of developed population centres, is the industry norm and also an industry trend with improving technology and commodity prices increasingly occurring in remote areas where these climatic events may not be well understood (Kumar et al. 2013b).

We know that climate is changing and that this will have differing implications at different regions. Explicit consideration of risks, costs and climate change is becoming increasingly common among large mining companies. The resulting closure options analyses and closure strategies may even occur in absence of regulatory requirement and, as a result, often go undocumented in publically available closure plans submitted to regulators (Mauric et al. 2012). Consideration of up to 1,000 year time frames for perpetual forces (weathering, erosion etc.) is becoming common. Equally, use of probably maximum flood (PMF) and maximum credible earthquake (MCE) for critical structures is now an industry norm for many mining jurisdictions (Jones 2012a).

A fundamental, but oft forgotten, consideration to mine closure is the trajectory of regulatory and social licences. Social expectation of company activities and of multinationals and the resource industry in particular, has consistently increased expectations. Social and environmental dimensions of mining regulation have also grown more stringent over the last few decades and can reasonably be expected to develop further. When we consider what regulations were in place, particularly in many developing countries, even just 10 or 20 years ago, this is particularly perceptible (Laurence 2006).

A company at a feasibility stage today with a mine life of around 15 years can expect closure under a much more stringent social and environmental context than when its initial closure plan first gained acceptance some 20 years prior. This significant risk is therefore best managed by developing initial closure strategies and following closure planning processes (such as stakeholder engagement, closure criteria etc.) at a preliminary but higher standard than what would likely be required for closure in the pre-feasibility stage (Figure 7).

\section{"IT'S ALL OK; WE'RE STILL HITTING THE TARGET!"}

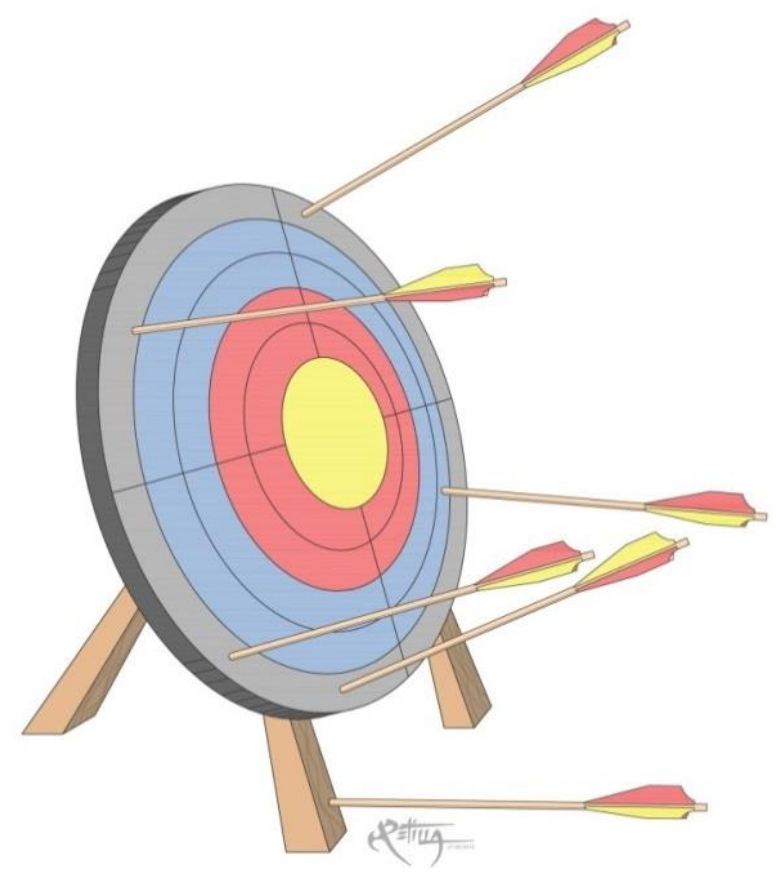

Figure 7 The closure target of tomorrow will likely be harder to hit than the target of today 


\section{$8 \quad$ Failure to have a clear objective and approach to closure}

A seventh lesson of closure planning is the failure to have a clear objective and approach to previously identified closure outcomes. Previous land uses may not be achievable and unrealistic goals for post-mining landscape (Figure 8). This may result in a focus on technical studies that fail to provide better closure understanding whilst expending hard-won closure budgets. Driving closure planning by well-defined goals through corporate tools such as closure standards designed to meet both internal requirements and relevant closure guidelines is an ideal solution to avoiding closure absolution (Garcia 2008).

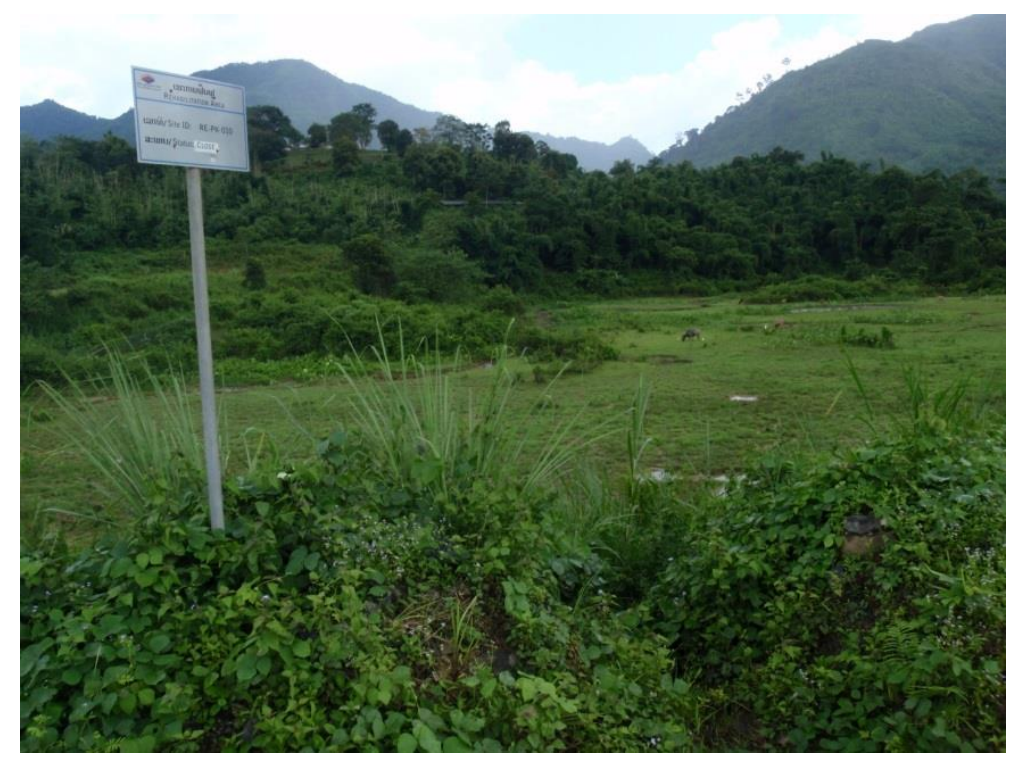

Figure 8 Rehabilitating hilly land into flat land gives, in this Laos operation, multiple land use opportunities for the surrounding community (Mauric et al. 2012)

Contaminated site legislation is increasingly considered in assessment of final land use appropriateness. Risk assessments also need to be undertaken at all stages of mining to inform planning (DITR 2015). There will likely be a need to undertake a number of trials and studies to test assumptions and close out knowledge gaps prior to definitive closure planning or any other 'Rubicon' stages of mine life when options and strategies may otherwise become effectively closed out. Closure planning should therefore incorporate physical and chemical safety, through to human and ecological risk. Mine closure planning of landforms should then be considered an exercise in constructing a new landscape and not just closing a mine.

- There may often be a lack of ownership for the closure process.

- Corporate may have the standard and vision but do not own the project; site does.

- Operational staff are often assumed to have closure in mind when undertaking their day-to-day activities or even planning. They regularly do not.

- Closure planning needs to be incorporated into all stages of mine life and not just the staff left holding the operation at closure.

\section{Summary and recommendations}

Mine closure benefits no involved party. Stakeholders such as Traditional Owners and the local community will lose jobs and be directly or indirectly affected by any liability of poor closure. Bonds provided to fund rehabilitation costs may be insufficient or may be diverted by governments into other purposes. Shareholders do not want to see their share price tracking backwards as accounting starts to include suddenly realised closure activity costs. 
Avoiding closure planning issues is typically cheaper and more practicable than trying to address problems, after they have presented, at mine completion. For example, best strategies are generally to ensure water does not contact any geological material with elevated geochemical concentrations; whether it is waste rock, low grade ore, or tailings. Some relaxation of mining's social and environmental (more the latter) laws have occurred in recent years in response to the global financial crisis (GFC) in some countries, such as northern Europe. Nonetheless, the international mining regulation and licence-to-operate trend is of a ratcheting effect - meaning that the regulation we meet today will have higher expectations in the regulatory environment of next year, the following decade or maybe an even further date in the future that closure actually occurs in.

Communities are also expecting faster reclamation through pressure for public access to reclaimed areas sooner (Ashton \& Evans 2005). However, reclamation cannot be considered wholly complete until the mine tenements are fully certified as relinquished and access made available to the public.

Industry case studies have shown that remedying closure liabilities is more expensive, unpredictable and takes longer to achieve than proactive operational management of risk with a view to closure to avoiding these liabilities in the first instance (Ziemkiewicz et al. 2001; Fletcher et al. 2012). Because the cost of closure can be substantial, net present value (NPV) is often used to provide closure cost estimates for the proposed closure date (Cowan et al. 2010). However, when consideration is given to the effect of NPV on closure costs, the financial incentive is to delay any closure expenses to as late as possible; such that timely closure planning decision-making and proactive closure works are then often not undertaken. There may therefore be little financial motivation to quantify closure costs with any particular rigour at the feasibility stage or to undertake the necessary rigour of closure planning and works (ICMM 2008). One only remedy to this is that shareholders are aware of closure financial liability when investing in mining companies for a long-term. Increased recognition of long-term implications of poor closure on environmental values and livelihoods from (relatively) short term gains during operations will drive an increasingly risk-averse social-licence-to-mine and regulatory climate. Another remedy is therefore that the obstacle of lost social licence to further mining development is seen as a cost worth addressing through better closure planning and practice prophylactically (Cowan et al. 2010).

In conclusion, closure planning should not simply be thought of as a land re-development exercise. Protection of environmental assets should consider a hierarchy of strategies such as avoidance, mitigation, restoration, offsets and additional conservation options (enhancements) (NSW EPA 2002; McCullough \& van Etten 2011). Even when clearly defined closure expectations are not available, the presence of international guidance (ICMM 2008) and transferability of general good closure principles can still enable well-directed closure planning to occur that provides sustainable social and environmental solutions (Mauric et al. 2012). Focus should be on understanding the (changing) social and environmental context, having a clear closure objective to work toward and on identifying how operational constraints, decisions and trade-offs will impinge on post-closure liability. Whilst avoidance of these key closure faults is no guarantee of successful relinquishment, recognition of these issues and judicious planning to overcome them is more likely to present well-considered closure plans.

\section{Acknowledgement}

Thanks to anonymous reviewers for their advice. Thanks also to Dave Salmon and Björn Weeks for constructive comments.

This paper is dedicated to the late Hugh Jones; regulator, consultant, colleague, mentor and friend.

\section{References}

Ashton, PJ \& Evans, LH 2005, 'Community development through minesite rehabilitation projects', in Proceedings, People Place Prosperity SD05 Sustainable Development Conference, Minerals Council of Australia.

Banks, D, Younger, PL \& Dumpleton, S 1997, 'The historical use of mine-drainage and pyrite-oxidation waters in central and eastern England, United Kingdom', Hydrology Journal, vol. 4, pp. 55-68. 
Botha, PR 2012, 'The business case for mine closure planning and an overview of Anglo American's mine closure toolbox approach', in Life-of-Mine Conference 2012, Australasian Institute of Mining and Metallurgy, Melbourne, pp. 7-9.

Bridge, G 2004, 'Contested terrain: mining and the environment', Annual Review of Environment and Resources, vol. 29, pp. $205-259$.

Castendyk, D, Eary, LE \& Balistrieri, LS 2014, 'Modeling and management of pit lake water chemistry 1: Theory', Applied Geochemistry, vol. 57, pp. 267-288.

CEMA 2012, End Pit Lakes Guidance Document, Cumulative Environmental Management Association, Calgary, p. 436.

Charette, T \& Wylynko, D 2011, 'Generating regional guidance for best practice for pit lake closure and reclamation', in Mine Pit Lakes: Closure and Management, CD McCullough (ed.), Australian Centre for Geomechanics, Perth.

Clark, I 1999, 'Planning for closure: The case of Australia', in A Warhurst \& L Noronha, (A Warhurst \& L Noronhas A Warhurst \& L Noronha (eds), Environmental policy in mining: Corporate strategy and planning for closure, Boca Raton, USA, Lewis Publishers.

Cowan, WR, Mackasey, WO \& Robertson, JGA 2010, Protection of environmental assets should consider a hierarchy of strategies such as avoidance, mitigation, restoration, offsets and additional conservation options (enhancements), National Orphaned/Abandoned Mines Initiative (NOAMI), Sudbury, Ontario, p. 140.

Davidson, NC 2014, 'How much wetland has the world lost? Long-term and recent trends in global wetland area', Marine and Freshwater Research, vol. 65, pp. 934-941.

Dickinson, S \& Berner, PO 2010, 'Ambatovy project: Mining in a challenging biodiversity setting in Madagascar', Malagasy Nature, vol. 3, pp. 2-13.

DITR 2015, Leading Practice Sustainable Development Program for the Mining Industry - Risk Assessment and Management, Department of Industry, Tourism and Resources, Canberra, Australia, p. 95.

DMP \& EPA (Western Australian Department of Mines and Petroleum \& Environmental Protection Authority of Western Australia) 2011, Guidelines for preparing mine closure plans, DMP \& EPA, Perth p. 78.

Doley, D \& Audet, P 2013, 'Adopting novel ecosystems as suitable rehabilitation alternatives for former mine sites', Ecological Processes, vol. 2, pp. 1-11.

Eary, T \& Castendyk, D 2012, 'Hardrock metal mine pit lakes: occurrence and geochemical characteristics', in W Geller, M Schultze, RLP Kleinmann \& C Wolkersdorfer (eds), Acidic Pit Lakes - Legacies of surface mining on coal and metal ores, Springer, Berlin.

Fletcher, D, Hutton, A \& Dick, C 2012, 'The 'Smoking Gun' of Detailed Mine Closure Cost Over-Run - A Review Using Case Studies of the Real Costs Associated with the Demolition and Removal of Infrastructure in Mine Closure', in Life-of-Mine Conference 2012, Australasian Institute of Mining and Metallurgy, Melbourne, pp. 325-332.

Gammons, CH \& Duaine, TE 2006, 'Long term changes in the limnology and geochemistry of the Berkely Pit Lake, Butte, Montana', Mine Water and the Environment, vol. 25, pp. 76-85.

Garcia, DH 2008, 'Overview of international mine closure guidelines', in Meeting of the American Institute of Professional Geologists, Arizona Hydrological Society, and 3rd International Professional Geology Conference, American Institute of Professional Geologists, pp. 1-9.

Hickey, CW \& Pyle, E 2001, 'Derivation of water quality guideline values heavy metals using a risk-based methodology: a site specific approach for New Zealand', Australasian Journal of Ecotoxicology, vol. 7, pp. 137-156.

ICMM (International Council on Mining and Metals) 2008, Planning for Integrated Mine Closure: Toolkit, ICMM, London, p. 86.

Jones, H 2008, 'Closure objectives, guidelines and actual outcomes', in AB Fourie, M Tibbett, IM Weiersbye \& P Dye (eds), Proceedings of the Third International Seminar on Mine Closure, Mine Closure 2008, Australian Centre for Geomechanics, Perth, pp. 245-254.

Jones, H 2012a, 'Closure objectives, guidelines and actual outcomes', in MJ Noakes (ed), Cost estimation handbook, Australasian Institute of Metals and Metallurgy (AusIMM), Sydney.

Jones, H 2012b, 'Rehabilitation levies', in AB Fourie \& M Tibbett (eds), Proceedings of the International Mine Closure 2013 Congress, Brisbane.

Jones, H \& McCullough, CD 2011, 'Regulator guidance and legislation relevant to pit lakes', in CD McCullough (ed), Mine Pit Lakes: Closure and Management, Australian Centre for Geomechanics, Perth, p. 183.

Jones, H \& Salmon, D 2012, 'Unintended consequences and mine closure', in AB Fourie \& M Tibbett (eds), Proceedings of the International Mine Closure 2012 Congress, Brisbane, pp. 703-716.

Kumar, NR, McCullough, CD \& Lund, MA 2013a, 'Upper and lower concentration thresholds for bioremediation of Acid Mine Drainage using bulk organic substrates', Mine Water and the Environment, vol. 32, pp. 285-292.

Kumar, RN, McCullough, CD \& Lund, MA 2013b, 'Pit lakes in Australia', in W Geller, M Schultze, RLP Kleinmann \& C Wolkersdorfer (eds), Acidic Pit Lakes - Legacies of surface mining on coal and metal ores, Springer, Berlin.

Laurence, D 2006, 'Optimisation of the mine closure process', Journal of Cleaner Production, vol. 14, pp. 285-298.

Loch, R \& Vacher, C 2006, 'Assessing and managing erosion risk for constructed landforms on minesites', in Proceedings of the Goldfields Environmental Management Group Workshop on Environmental Management 2006, pp. 121-127.

Lord, MT, Adams, MH \& Shearman, TJ 2015, 'Century mine closure', in Proceedings of the International Mine Closure 2015 Congress, Infomine, pp. 1-12.

McCullough, CD 2015, 'Consequences and opportunities of river breach and decant from an acidic mine pit lake', Ecological Engineering, vol. 85, pp. 328-338.

McCullough, CD \& Lund, MA 2011, 'Bioremediation of Acidic and Metalliferous Drainage (AMD) through organic carbon amendment by municipal sewage and green waste', Journal of Environmental Management, vol. 92, pp. 2419-2426. 
McCullough, CD \& Pearce, Jl 2014, 'What do elevated background contaminant concentrations mean for AMD risk assessment and management in Western Australia?', in 8th Australian Workshop on Acid and Metalliferous Drainage, pp. 147-158.

McCullough, CD \& van Etten, EJB 2011, 'Ecological restoration of novel lake districts: new approaches for new landscapes', Mine Water and the Environment, vol. 30, pp. 312-319.

McCullough, CD, Ballot, E \& Short, D 2013a, 'Breach and decant of an acid mine lake by a eutrophic river: river water quality and limitations of use', in Proceedings of the Mine Water Solutions 2013 Congress, Infomine Inc., pp. 317-327.

McCullough, CD, Marchand, G \& Unseld, J 2013b, 'Mine closure of pit lakes as terminal sinks: best available practice when options are limited?', Mine Water and the Environment, vol. 32, pp. 302-313.

Maron, M 2012, 'Faustian bargains? Restoration realities in the context of biodiversity offset policies', Biological Conservation, vol. 155, pp. 141-148.

Mauric, AP, McCullough, CD, Wilson-Clark, C, Witcomb, A \& Millgate, J 2012, 'Closure Planning in a Developing country - a case study from the Phu Kham Mine, Laos, South-east Asia', in AB Fourie \& M Tibbett (eds), Proceedings of the International Mine Closure 2012 Congress, pp. 295-304.

Nelson, J \& Scoble, M 2005, 'Social license to operate mines: issues of situational analysis and process', in M Hardygóra \& G Paszkowska (eds), Proceedings of the Mine Planning and Equipment Selection (MPES) Conference, AA Balkema Publishers, p. 21.

Newmont Golden Ridge Limited 2009, BBOP Pilot Project Case Study, Akyem Gold Mining Project, Eastern Region, Ghana, Accra, Ghana, www.forest-trends.org/biodiversityoffsetprogram/guidelines/newmont-casestudy.pdf

Nieto, JM, Sarmiento, AM, Canovas, CR, Olias, M \& Ayora, C 2013, 'Acid mine drainage in the Iberian Pyrite Belt: 1. Hydrochemical characteristics and pollutant load of the Tinto and Odiel rivers', Environmental Science and Pollution Research International, vol. 20, pp. 1320-1356.

NSW EPA (New South Wales Environmental Protection Authority) 2002, Green offsets for sustainable development, a concept paper, NSW EPA, Sydney, p. 16.

Olias, M \& Nieto, JM 2015, 'Background Conditions and Mining Pollution throughout History in the Río Tinto (SW Spain)', Environments, vol. 2, pp. 295-316.

Puhalovich, AA \& Coghill, M 2011, 'Management of mine wastes using pit/underground void backfilling methods: current issues and approaches', in CD McCullough (ed.), Mine Pit Lakes: Closure and Management, Australian Centre for Geomechanics, Perth.

Schaefer, JA 2009, 'Risk evaluation of dams on karst foundations', in Proceedings of 29th Annual USSD Conference, pp. 541-579.

Schultze, M, Boehrer, B, Friese, K, Koschorreck, M, Stasik, S \& Wendt-Potthoff, K 2011, 'Disposal of waste materials at the bottom of pit lakes', in AB Fourie, M Tibbett \& A Beersing (eds), Mine Closure 2011: Proceedings of the Sixth International Conference on Mine Closure, Australian Centre for Geomechanics, Perth, pp. 555-564.

Siwik, R \& Clemens, M 2015, 'Mine closure - past, present and perpetuity', in Proceedings of the International Mine Closure 2015 Congress, Infomine, pp. 1-10.

Skousen, J \& Zipper, C 2014, 'Post-mining lands use options in the Appalachian Coal Mining Region of the USA', in Proceedings of Life of Mine Conference, pp. 153-164.

Swanson, S 2011, 'What type of lake do we want? Stakeholder engagement in planning for beneficial end uses of pit lakes', in CD McCullough (ed.), Mine Pit Lakes: Closure and Management, Australian Centre for Geomechanics, Perth.

Vandenberg, J, Lauzon, N, Prakash, S \& Salzsauler, K 2011, 'Use of water quality models for design and evaluation of pit lakes', in CD McCullough (ed.), Mine Pit Lakes: Closure and Management, Australian Centre for Geomechanics, Perth.

Vink, S 2012, 'Pit lakes as evaporative 'terminal' sinks: an approach to best available practice mine closure', in Proceedings of the International Mine Water Association (IMWA) Congress, International Mine Water Association (IMWA), pp. 167-174.

Younger, PL 2002, Mine waste or mine voids: which is the most important long-term source of polluted mine drainage?, United Nations Environment Programme, Mineral Resources Forum: Current Feature paper, p. 12.

Ziemkiewicz, P, Skousen, J \& Simmons, J 2001, 'Cost benefit analysis of passive treatment systems', in Proceedings 22nd West Virginia Surface Mine Drainage Task Force Symposium, Morgantown, West Virginia.

Zschiedrich, K 2004, '15 years of restoration and rehabilitation of former lignite mining facilities - Present status and future development in Germany's Lusatian mining district', World of Mining - Surface and Underground, vol. 56, pp. 348-359. 